\author{
Marija Jozipović \\ Petra Ramljak \\ Iva Renić \\ Sveucíliste u Zagrebu, Edukacijsko-rehabilitacijski \\ fakultet, studentice
}

\section{Logopedska praksa s poremećajima glasa $u$ Hrvatskoj}

\author{
Speech-language therapy practice \\ with voice disorders in Croatia
}

Stručni rad UDK: 616.22-008.5:376(497.5) https://doi.org/10.31299/log.10.1.3

\begin{abstract}
SAŽETAK
Poremećaji glasa dio su logopedske djelatnosti koja uključuje prevenciju, dijagnostiku i terapiju za poboljšanje glasovne proizvodnje. Cilj ovog istraživanja je dobivanje boljeg uvida u logopedski rad u kontekstu poremećaja glasa u Republici Hrvatskoj, što pridonosi unapređenju obrazovanja i logopedske djelatnosti u navedenom području. Istraživanje je bilo namijenjeno radno aktivnim logopedima iz Republike Hrvatske, a provedeno je elektroničkom anketom pod nazivom „Praksa poremé́aja glasa $u$ Hrvatskoj". Anketa je sadržavala ukupno 22 ispitne čestice, koje su se odnosile na sljedeća područja: a) educiranost i znanja sudionika o poremećajima glasa, b) iskustvo u radu s populacijom s poremećajem glasa i c) mišljenja o mogućim rješenjima za unapređenje prakse poremećaja glasa u Republici Hrvatskoj. U istraživanju je sudjelovalo 108 logopeda iz šesnaest županija. Problematika poremećaja glasa u općoj populaciji još nije dovoljno osviještena, a postoji potreba za njenim prepoznavanjem i tretiranjem. Istraživanje je pokazalo da logopedi nakon studija osjećaju nedostatak kompetencija za pružanje logopedskih usluga osobama s poremećajima glasa. Dodatno zabrinjava činjenica da se osjećaj kompetencije ne povećava radnim iskustvom, već uglavnom ostaje isti. Zaključno, na osnovi rezultata ovog istraživanja, postoji potreba za unapređenjem obrazovanja i rada u području poremećaja glasa s više kolegija u planu i programu studija, više sati prakse, čitanja stručnih članaka, pohađanja edukacija i boljeg umrežavanja logopeda.
\end{abstract}

\begin{abstract}
Speech and language pathology includes prevention, assessment, diagnostics and therapy of voice disorders in order to improve voice production. The main goal of this research is to gain insight into speech and language pathologist's (SLP) practice in the field of voice pathology in Croatia, which could enable practice and education improvements. The research was carried out among employed speech and language pathologists using an online survey called Voice disorders practice in Croatia. The survey consisted of 22 items divided into following parts: a) participants' knowledge and education in voice disorders, b) their clinical experience with voice disorders, and c) outlook on possible solutions for practice improvement. The total of 108 SLPs from different parts of Croatia filled out the survey. Data was analyzed using descriptive and nonparametric statistical method. Lack of awareness in voice disorders is still considered an issue among general population. There is still the need for its recognition and treatment. Results show that SLPs do not feel competent enough to use their knowledge in voice pathology after finishing their studies. Additional concern is that feeling of competence does not increase among SPLs with more years of working experience. According to the results of this research, it is necessary to improve education and practice in the field of voice disorders in the form of more courses, practical experience, reading of scientific literature, workshops and networking among experts.
\end{abstract}

Ključne riječi: poremećaji glasa - logoped praksa u Republici Hrvatskoj

Keywords: voice disorders - speech and language pathology clinical practice in Croatia 


\section{UVOD}

Poremećaji glasa jedna su od temeljnih logopedskih disciplina. Logopedski rad uključuje prevenciju, dijagnostiku i terapiju poremećaja glasa, a usmjeren je poboljšanju glasovne proizvodnje, koordinacije disanja, laringealnog ventila i/ili usvajanja alaringealnog govora - dostatnog za funkcionalnu oralnu komunikaciju. To bi trebalo dovesti do poboljšanja vokalnih funkcija i sposobnosti, učinkovitijeg i jednostavnijeg sudjelovanja u svakodnevnom životu (American Speech-Language-Hearing Association, 2004). Intervencija u području poremećaja glasa potrebna je pojedincima s poremećajima glasa, alaringealnim govorom i/ili laringealnim teškoćama koje pogađaju disanje, a problemi mogu biti organske, neurološke, bihevioralne i psihosocijalne etiologije. Posebne vokalne potrebe mogu biti povezane sa zanimanjem, rekreacijom ili izražavanjem specifičnih osobnih obilježja i emocija. Te opće i specifične potrebe postaju cilj vokologa u okvirima prevencije, procjene i intervencije (Titze i Verdolini, 2010).

Procjena poremećaja glasa može uključivati subjektivnu i objektivnu procjenu, dok se terapija provodi izravnim (engl. direct) $\mathrm{i} / \mathrm{ili}$ neizravnim (engl. indirect) pristupima. Izravni pristupi obuhvaćaju opću ili specifičnu (simptomatsku) terapiju i uključuju manipulaciju vokalnim mehanizmom (fonacijom, rezonancijom i mišićnom funkcijom) radi uspostave zdrave vokalne produkcije. Neizravni pristupi se odnose na promjenu kognitivne, bihevioralne, psihološke fizičke okoline u kojoj se stvara glas, a uključuju edukaciju i savjetovanje.

Izbor terapije ovisi o sljedećim varijablama (ASHA, 2019):

a) prirodi poremećaja (etiologiji i stupnju),

b) klijentu (dobi, profesiji, motivaciji),

c) mogućnostima klijenta za uključivanje u terapiju

(slobodnom vremenu, financijskom stanju),

d) terapeutu (znanju, iskustvu, osjećaju sigurnosti pri pružanju terapije).

Vokalna edukacija uključuje „razvijanje svijesti o vlastitom glasu, poznavanje anatomije i fiziologije vokalnog aparata, vokalne higijene i vokalnih tehnika" (Kovačić i Buđanovac, 2000, str. 38). Vokalna higijena, kao dio vokalne edukacije, uključuje brigu za glas, a počinje osvještavanjem i uočavanjem čimbenika koji pozitivno i negativno utječu na glas. Program vokalne higijene uključuje edukaciju o vokalnom mehanizmu, prepoznavanju i smanjenju nepoželjnih ponašanja (npr. dehidracija, vikanje, plakanje, pročišćavanje grla), očuvanju glasa i vokalnom odmoru. Drugim riječima, vokalna higijena podrazumijeva usvajanje načela poboljšanja vokalnog zdravlja, redovitu i zdravu prehranu, dostatnu hidrataciju, kontrolu laringofaringealnog i gastroezofagealnog refluksa, iritacija $i$ alergija (Behlau i Olivera, 2009). „Vokalna higijena, zapravo je i više od toga proces oblikovanja i usvajanja ponašanja koja se konstantno prakticiraju u svakodnevnom životu, te postaje životnim stilom" (Kovačić i Buđanovac, 2000, str. 38/39). Savjetovanje o vokalnoj higijeni odvija se usmenim ili pisanim putem radi prevencije poremećaja glasa, odnosno poboljšanja vokalnih parametara i smanjena vokalnog rizika (Pasa, Oates i Dacakis, 2007; Chan, 1994; Yiu i Chan, 2003). Ponekad ih terapeuti primjenjuju i kao terapijsku strategiju, premda Behlau i Olivera (2009) smatraju da vokalna higijena treba biti samo dio šireg rehabilitacijskog programa.

U Europi je nesrazmjer broja logopeda i ukupnog broja stanovnika. U Hrvatskoj je najveći problem centralizacija logopedske djelatnosti. Naime, više od polovice logopeda zaposleno je u Zagrebu i okolici, time deficitarnost logopedije u Gradu Zagrebu i Zagrebačkoj županiji opada (Hrvatski zavod za zapošljavanje, 2018), a postoje županije u kojima radi svega jedan ili dva logopeda. Dijelovi Hrvatske otoci, Lika, Dalmatinska zagora, Baranja i Primorje - gotovo i nemaju logopeda. Potrebe za logopedima u Hrvatskoj su velike, ali broj zaposlenih logopeda nije dostatan, odnosno ne zadovoljava potražnju. Nedostatak logopeda u određenim županijama stavlja dodatni teret na Zagreb, čime ni tamošnji stručnjaci više ne mogu zadovoljiti hrvatske potrebe za logopedskim uslugama.

\section{CILJ ISTRAŽIVANJA}

S obzirom na neujednačenu raspodjelu logopedske djelatnosti i nedostatak informacija o logopedskoj djelatnosti u području poremećaja glasa u Republici Hrvatskoj, cilj ovog istraživanja je pridonijeti boljem uvidu u logopedski rad u kontekstu poremećaja glasa. Time se potencijalno želi pridonijeti budućem napretku u obrazovanju i kliničkoj praksi.

S obzirom na cilj istraživanja, postavljena su sljedeća istraživačka pitanja:

1. U kojem sustavu osobe s poremećajima glasa najčešće dobivaju logopedske usluge?

2. Osjećaju li se logopedi nakon završetka studija kompetentnima za rad s osobama s poremećajima glasa?

Iz istraživačkih pitanja slijede postavljene hipoteze:

H1: Osobe s poremećajima glasa češće logopedske usluge dobivaju u sustavu zdravstva, nego u drugim sustavima.

H2: Logopedi se nakon završetka studija osjećaju djelomično kompetentnima $\mathrm{za}$ rad $\mathrm{s}$ osobama s poremećajima glasa.

Tablica 1. Raspodjela sudionika istraživanja prema županijama

\begin{tabular}{|l|c|c|}
\hline Naziv županije & Frekvencija & Postotak \\
\hline Grad Zagreb & 49 & 45,5 \\
\hline Zagrebačka & 18 & 16,7 \\
\hline Splitsko-dalmatinska & 10 & 9,3 \\
\hline Primorsko-goranska & 5 & 4,6 \\
\hline Istarska & 5 & 4,6 \\
\hline Karlovačka & 4 & 3,7 \\
\hline Varaždinska & 3 & 2,8 \\
\hline Međimurska & 3 & 2,8 \\
\hline Krapinsko-zagorska & 2 & 1,9 \\
\hline Zadarska & 2 & 1,9 \\
\hline Osječko-baranjska & 2 & 1,9 \\
\hline Sisačko-moslavačka & 1 & 0,9 \\
\hline Koprivničko-križevačka & 1 & 0,9 \\
\hline Bjelovarsko-bilogorska & 1 & 0,9 \\
\hline Virovitičko-podravska & 1 & 0,9 \\
\hline Požeško-slavonska & 1 & 0,9 \\
\hline
\end{tabular}




\section{METODE}

\section{Sudionici istraživanja}

Istraživanje je bilo namijenjeno radno aktivnim logopedima, u kojem je sudjelovalo 108 logopeda iz 16 županija (tablica 1). Iz Ličko-senjske, Brodsko-posavske, Šibensko-kninske, Vukovarsko-srijemske i Dubrovačkoneretvanske županije - nije bilo sudionika. Najviše logopeda je sudjelovalo iz Grada Zagreba i Zagrebačke županije, što je očekivano s obzirom na najveći broj zaposlenih logopeda $\mathrm{u}$ tom makroregionalnom središtu Hrvatske. Udjelom po broju sudionika, sljedeća je Splitsko-dalmatinska županija. Informacije o sudionicima (spol, radni odnos, radno mjesto, godine radnog staža, obrazovanje, populacija s kojom najčešće rade) prikazuje tablica 2.

Tablica 2. Opći podaci o sudionicima istraživanja

\begin{tabular}{|c|c|c|c|}
\hline & & Frekvencija & Postotak \\
\hline \multirow{2}{*}{ Spol } & Muško & 2 & 1,9 \\
\hline & Žensko & 106 & 98,1 \\
\hline \multirow{3}{*}{$\begin{array}{l}\text { Radni } \\
\text { odnos }\end{array}$} & $\begin{array}{l}\text { Zaposlen/a na } \\
\text { puno radno vrijeme }\end{array}$ & 105 & 97,2 \\
\hline & $\begin{array}{l}\text { Zaposlen/a na pola } \\
\text { radnog vremena }\end{array}$ & 2 & 1,9 \\
\hline & $\begin{array}{l}\text { Pripravnik na puno } \\
\text { radno vrijeme }\end{array}$ & 1 & 0,9 \\
\hline \multirow{5}{*}{$\begin{array}{l}\text { Radno } \\
\text { iskustvo }\end{array}$} & Do 5 godina & 46 & 42,6 \\
\hline & 6-10 godina & 22 & 20,4 \\
\hline & $11-15$ godina & 19 & 17,6 \\
\hline & 16-20 godina & 11 & 10,2 \\
\hline & Više od 20 godina & 10 & 9,3 \\
\hline \multirow{5}{*}{ Sprema } & $\begin{array}{l}\text { Cetverogodišnji } \\
\text { studij prije Bolonje }\end{array}$ & 38 & 35,2 \\
\hline & $\begin{array}{l}\text { Preddiplomski } \\
\text { studij }\end{array}$ & 1 & 0,9 \\
\hline & $\begin{array}{l}\text { Diplomski } \\
\text { studij/magisterij } \\
\text { struke }\end{array}$ & 63 & 58,3 \\
\hline & Specijalistički studij & 5 & 4,6 \\
\hline & Doktorski studij & 1 & 0,9 \\
\hline \multirow{6}{*}{$\begin{array}{l}\text { Radno } \\
\text { mjesto }\end{array}$} & $\begin{array}{l}\text { Predškolski odgoj i } \\
\text { obrazovanje (vrtić) }\end{array}$ & 29 & 26,9 \\
\hline & Škola & 27 & 25,0 \\
\hline & Socijalna skrb & 7 & 6,5 \\
\hline & Zdravstvo & 26 & 24,1 \\
\hline & Privatna praksa & 15 & 13,9 \\
\hline & Udruga & 4 & 3,7 \\
\hline \multirow{7}{*}{$\begin{array}{l}\text { Dob } \\
\text { populacije } \\
\text { korisnika } \\
\text { (pitanje } \\
\text { višestrukog } \\
\text { izbora) }\end{array}$} & $0-3$ godine & 36 & 33,3 \\
\hline & 4-6 godina & 73 & 67,6 \\
\hline & 7-11 godina & 61 & 56,5 \\
\hline & $12-18$ godina & 17 & 15,7 \\
\hline & 19-30 godina & 3 & 2,8 \\
\hline & 31-55 godina & 8 & 7,4 \\
\hline & 56 i više godina & 8 & 7,4 \\
\hline
\end{tabular}

\section{Ispitni materijal i način provedbe istraživanja}

Radi osiguravanja dostupnosti i dinamike provedbe, oblikovana je elektronička anketa pod nazivom „Praksa poreméaja glasa u Hrvatskoj”, on-line upitnikom „Google obrasci“ (prilog 1). Anketa je sadržavala ukupno 22 ispitne čestice. Ispitne čestice su bile zatvorenog tipa, a rezultati i njihova interpretacija prikazani su prema sljedećim područjima: a) opće informacije o sudionicima istraživanja (čestice 1-5; 12-13), b) educiranost i znanje o poremećajima glasa (čestice 6-11), c) rad s populacijom s poremećajima glasa (čestice 14-18), d) moguća rješenja za unapređenje obrazovanja o poremećajima glasa (čestice 17-22).

Konačna verzija upitnika podignuta je na platformu Facebook u grupu „Logopedi HR“, u kojoj su logopedi iz Republike Hrvatske, a dijelu sudionika upitnik je poslan osobno elektroničkom poštom.

\section{Obrada podataka}

Statistička obrada podataka uključila je deskriptivnu statistiku te neparametrijsku statistiku (Spearmanov koeficijent korelacije, analiza varijance).

\section{REZULTATI I RASPRAVA}

\section{Educiranost i znanje o poremećajima glasa}

Čestice koje su se odnosile na znanje logopeda i njihovu educiranost o poremećajima glasa obuhvatile su znanje stečeno tijekom studija logopedije (6-8) i ono naknadno stečeno (9-11).

\section{Educiranost $i$ znanje o poremé́ajima glasa tijekom studija logopedije}

$\mathrm{U}$ čestici 6 sudionicima je ponuđen višestruki odabir odgovora. Odgovori sudionika svjedoče da su tijekom studija gotovo svi sudionici slušali predavanja o poremećajima glasa kod djece, a tek petina sudionika o vokologiji. Svaku od ponuđenih tema odabrao je barem dio sudionika (slika 1).

Česticom 8 ispitan je osjećaj pripremljenosti logopeda za rad u području poremećaja glasa nakon završetka studija. Usprkos činjenici da je više od polovine sudionika za vrijeme studija imalo vježbe i/ili praksu iz područja poremećaja glasa (čestica 7), podjednak udio sudionika navodi osjećaj nepripremljenosti $\mathrm{za}$ rad $\mathrm{s}$ populacijom osoba $\mathrm{s}$ poremećajima glasa. Najmanji udio logopeda osjeća se pripremljeno za rad te vrste. Opciju "vrlo pripremljeno" nije odabrao niti jedan sudionik.

Podaci o vježbama/praksi tijekom studija i osjećaju pripremljenosti nakon studija prikazani su u tablici 3 .

\section{Dobiveno żnanje u podruc̆ju poreméaja glasa nakon studija logopedije}

Čestice 9-11 odnosile su se na znanje i vještine $u$ području poremećaja glasa stečene nakon završetka studija. 
Obuhvaćale su pitanja o sudjelovanju na edukacijama i radionicama $s$ temama iz područja poremećaja glasa, učestalosti čitanja stručne literature o poremećajima glasa, trenutnom osjećaju sposobnosti pružanja logopedskih usluga osobama s poremećajima glasa nakon određenog razdoblja radnog iskustva.

Tablica 3. Podaci o vježbama/praksi tijekom studija i osjećaju pripremljenosti nakon studija

\begin{tabular}{|c|c|c|c|}
\hline & & $\mathbf{F}$ & $\mathbf{P}$ \\
\hline \multirow{2}{*}{$\begin{array}{l}\text { Vježbe/praksa } \\
\text { tijekom studija }\end{array}$} & $\mathrm{Ne}$ & 42 & 38.9 \\
\hline & $\mathrm{Da}$ & 66 & 61.1 \\
\hline \multirow{4}{*}{$\begin{array}{l}\text { Osjećaj } \\
\text { pripremljenosti } \\
\text { za rad s } \\
\text { poremećajima } \\
\text { glasa }\end{array}$} & Nepripremljeno & 65 & 60.2 \\
\hline & $\begin{array}{l}\text { Donekle } \\
\text { pripremljeno }\end{array}$ & 40 & 37.0 \\
\hline & Pripremljeno & 3 & 2.8 \\
\hline & Vrlo pripremljeno & 0 & 0.0 \\
\hline
\end{tabular}

Legenda: $\mathrm{F}=$ frekvencija sudionika; $\mathrm{P}=$ udio u ukupnom broju sudionika

Tablica 4. Podaci o stjecanju znanja nakon završetka studija i osjećaju sposobnosti za rad nakon određenog razdoblja radnog iskustva

\begin{tabular}{|c|c|c|c|}
\hline & & $\mathbf{F}$ & $\mathbf{P}$ \\
\hline \multirow{3}{*}{$\begin{array}{l}\text { Sudjelovanje na } \\
\text { predavanjima ili } \\
\text { radionicama }\end{array}$} & $\begin{array}{l}\text { Nikad nisam } \\
\text { sudjelovao/la }\end{array}$ & 68 & 63.0 \\
\hline & $\begin{array}{l}\text { Ponekad } \\
\text { sudjelujem }\end{array}$ & 36 & 33.3 \\
\hline & Često sudjelujem & 4 & 3.7 \\
\hline \multirow{4}{*}{$\begin{array}{l}\text { Učestalost čitanja } \\
\text { stručne literature }\end{array}$} & Nikad & 23 & 21.3 \\
\hline & Gotovo nikad & 34 & 31.5 \\
\hline & Ponekad & 40 & 37.0 \\
\hline & Često & 7 & 6.5 \\
\hline \multirow{4}{*}{$\begin{array}{l}\text { Osjećaj sposobnosti } \\
\text { pružanja usluge } \\
\text { danas }\end{array}$} & $\begin{array}{l}\text { Ne osjećam se } \\
\text { sposobno }\end{array}$ & 53 & 49.1 \\
\hline & $\begin{array}{l}\text { Osjećam se } \\
\text { donekle sposobno }\end{array}$ & 45 & 41.7 \\
\hline & $\begin{array}{l}\text { Osjećam se } \\
\text { sposobno }\end{array}$ & 4 & 3.7 \\
\hline & $\begin{array}{l}\text { Osjećam se vrlo } \\
\text { sposobno }\end{array}$ & 6 & 5.5 \\
\hline
\end{tabular}

Legenda: $\mathrm{F}=$ frekvencija sudionika; $\mathrm{P}=$ udio u ukupnom broju sudionika

\section{Dobiveno znanje u području poremé́aja glasa nakon studija logopedije}

Čestice 9-11 odnosile su se na znanje i vještine $u$ području poremećaja glasa stečene nakon završetka studija. Obuhvaćale su pitanja o sudjelovanju na edukacijama i radionicama s temama iz područja poremećaja glasa, učestalosti čitanja stručne literature o poremećajima glasa, trenutnom osjećaju sposobnosti pružanja logopedskih usluga osobama s poremećajima glasa nakon određenog razdoblja radnog iskustva.

Većina sudionika nikad nije sudjelovala na edukacijama i/ili radionicama nakon studija, premda više od trećine njih navodi da stručnu literaturu čita, barem, ponekad. Ipak, znatno više zabrinjava činjenica da gotovo polovina sudionika navodi kako se ni danas, nakon određenog razdoblja radnog iskustva, ne osjeća sposobno pružati logopedske usluge populaciji osoba s poremećajem glasa. Tek manje od $10 \%$ sudionika osjeća se sposobno ili vrlo sposobno pružati takve usluge. Podaci o stjecanju znanja nakon završenog studija, te osjećaju sposobnosti za rad s populacijom osoba s poremećajima glasa nakon određenog razdoblja radnog iskustva, prikazuje tablica 4.

Rezultati analize varijance potvrđuju statistički značajne razlike u osjećaju sposobnosti za rad u području poremećaja glasa između logopeda zaposlenih u različitim sustavima $(\mathrm{p}<0.05)$. Najsposobnijima se osjećaju logopedi zaposleni u zdravstvenom sustavu (tablica 5), iako taj osjećaj ne podliježe razlikama s obzirom na broj godina radnog staža.

\section{Jeste li na fakultetu slušali predavanja o sljedećim temama?}

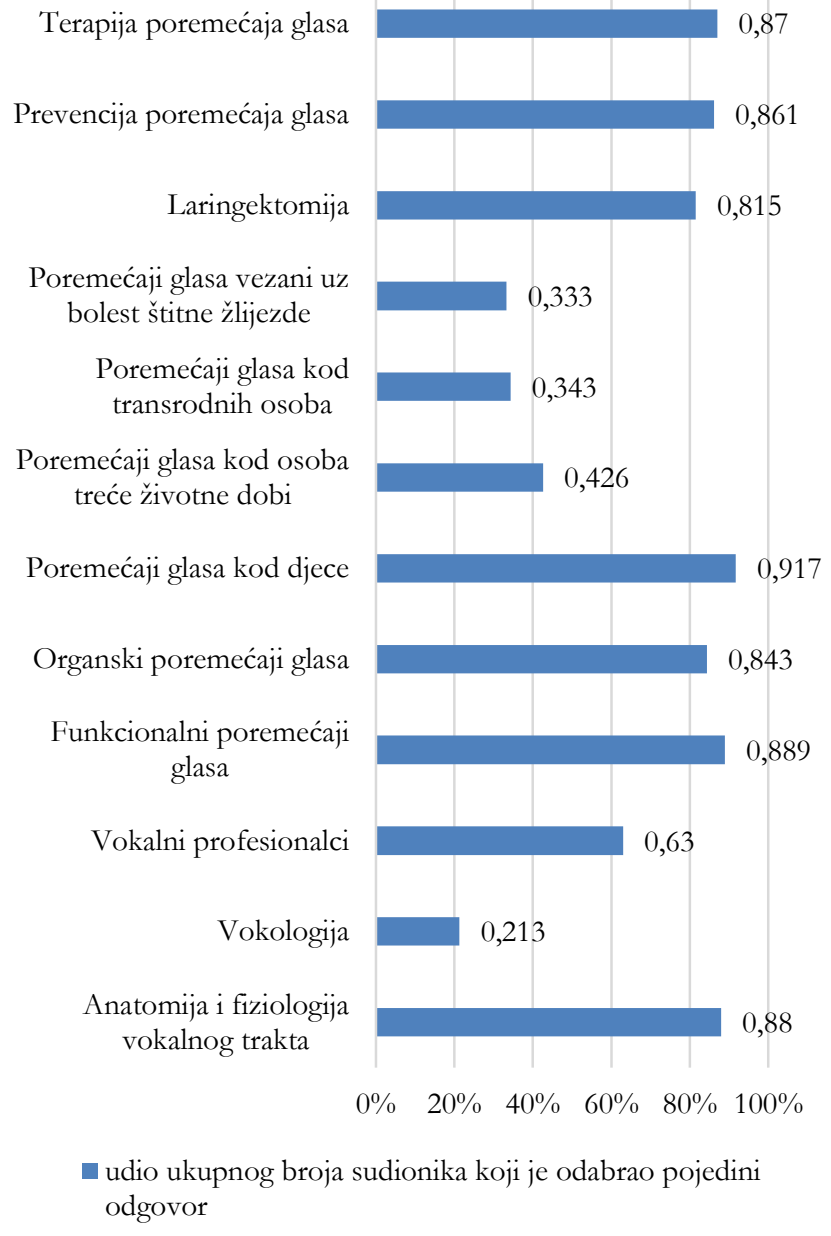

Slika 1. Podaci o odgovorima sudionika vezanim uz teme predavanja specifične za područja poremećaja glasa, o kojima su slušali tijekom studija logopedije

\section{Rad s poremećajima glasa}

Čestice 14-17 se odnose na rad s populacijom poremećaja glasa, odnosno iskustvo u procjeni i terapiji poremećaja glasa.

Većina logopeda u ovom istraživanju rijetko se bavi 
problematikom poremećaja glasa. Gotovo trećina sudionika u svom radu se uopće ne susreće s osobama s poremećajem glasa. Tri sudionika koja pretežito pružaju logopedske usluge navedenoj populaciji, zaposlena su u zdravstvenom sustavu (tablica 6).

Tablica 5. Deskriptivni podaci analize varijance osjećaja sposobnosti za rad logopeda zaposlenih u različitim sustavima

\begin{tabular}{|l|c|c|c|c|}
\hline SUSTAV & M & SD & Min & Max \\
\hline $\begin{array}{l}\text { Predškolski } \\
\text { odgoj i } \\
\text { obrazovanje } \\
\text { (vrtić) }\end{array}$ & 1,31 & 0,491 & 1 & 2 \\
\hline Škola & 1,61 & 0,555 & 1 & 3 \\
\hline Socijalna skrb & 1,43 & 0,535 & 1 & 2 \\
\hline Zdravstvo & 2,19 & 1,234 & 1 & 5 \\
\hline Privatna praksa & 1,47 & 0,640 & 1 & 3 \\
\hline Udruga & 2 & 0,816 & 1 & 3 \\
\hline
\end{tabular}

Legenda: $\mathrm{M}=$ aritmetička sredina; $\mathrm{SD}=$ standardna devijacija; Min=minimalni rezultat; $\mathrm{Max}=$ maksimalni rezultat

U 15., 16. i 17. čestici upitnika sudionicima je ponuđen višestruki odabir odgovora.

Više od polovine sudionika navodi da ne provodi logopedsku procjenu kvalitete glasa. Logopedi koji provode procjenu najčešće se služe logopedskim intervjuom, procjenom perceptivnim ljestvicama (GRBAS i sl.), objektivnom procjenom akustičkih parametara, a najrjeđe upitnicima za samoprocjenu (VHI, VOISS i sl.).

Tablica 6. Raspodjela učestalosti poremećaja glasa s obzirom na sustav u kojem logoped radi

\begin{tabular}{|c|c|c|c|c|c|}
\hline \multirow[b]{2}{*}{ SUSTAV } & \multicolumn{5}{|c|}{ Postotak poremećaja glasa u radu } \\
\hline & $\mathbf{0}$ & $\begin{array}{l}<25 \\
\%\end{array}$ & $\begin{array}{c}25-50 \\
\%\end{array}$ & $\begin{array}{c}51-75 \\
\%\end{array}$ & $\begin{array}{c}>75 \\
\%\end{array}$ \\
\hline $\begin{array}{l}\text { Predškolski } \\
\text { odgoj i } \\
\text { obrazovanje } \\
\text { (vrtić) }\end{array}$ & 8 & 20 & 1 & 0 & 0 \\
\hline Škola & 9 & 18 & 0 & 0 & 0 \\
\hline $\begin{array}{l}\text { Socijalna } \\
\text { skrb }\end{array}$ & 3 & 4 & 0 & 0 & 0 \\
\hline Zdravo & 4 & 17 & 2 & 0 & 3 \\
\hline $\begin{array}{l}\text { Privatna } \\
\text { praksa }\end{array}$ & 10 & 5 & 0 & 0 & 0 \\
\hline Udruga & 1 & 3 & 0 & 0 & 0 \\
\hline $\begin{array}{l}\text { Ukupna } \\
\text { učestalost } \\
\text { poremećaja } \\
\text { glasa u } \\
\text { radu } \\
\text { logopeda }\end{array}$ & $\begin{array}{c}35 \\
(32,4 \%)\end{array}$ & $\begin{array}{c}67 \\
(62,0 \%)\end{array}$ & $\begin{array}{c}3 \\
(2,8 \%)\end{array}$ & $\begin{array}{c}0 \\
(0.0 \%)\end{array}$ & $\begin{array}{c}3 \\
(2,8 \%)\end{array}$ \\
\hline
\end{tabular}

Jednako kao i procjenu, više od polovine sudionika uopće ne provodi terapiju poremećaja glasa. Od sudionika koji navode da provode glasovnu terapiju, gotovo polovina provodi neizravnu terapiju, koja se odnosi na savjete o vokalnoj higijeni, vokalnom odmoru i relaksaciji. Tek nekolicina sudionika provodi izravnu terapiju (opću ili specifičnu; simptomatsku), a samo jedan sudionik vježbe za opuštanje i zaštitu glasnica.

\section{Provodite li procjenu poremećaja glasa?}

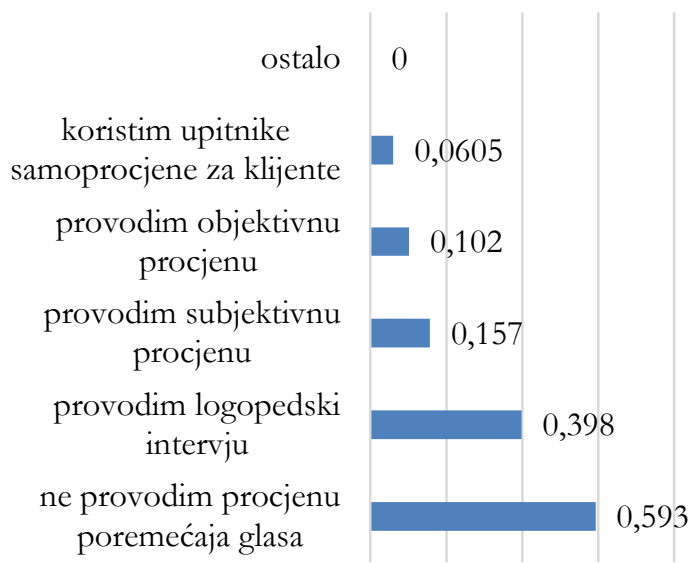

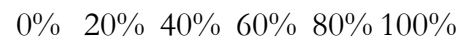

- udio ukupnog broja sudionika koji je odabrao pojedini odgovor

Slika 2. Podaci o odgovorima sudionika o provedbi procjene poremećaja glasa

Podaci o načinu provedbe procjene (slika 2) i terapije (slika 3) prikazani su u nastavku.

Od ponuđenih razloga zbog kojih ne provode procjenu i terapiju, sudionici dominantno navode kako one nisu prioritet u opisu njihovog radnog mjesta ili da se na svom radnome mjestu ne susreću s poremećajima glasa. Također, više od polovine sudionika osobe s poremećajima glasa usmjeri drugom stručnjaku (ORL stručnjaku, psihologu/psihijatru, drugom logopedu koji se bavi poremećajima glasa). Pod opcijom "ostalo", sudionici samostalno navode problem nesrazmjera broja logopeda i klijenata, pogotovo u području (pred)školskog odgoja i obrazovanja. Također navode manjak zanimanja za područje poremećaja glasa te navode nedostatna znanja i sposobnosti za provedbu kvalitetne procjene i terapije.

Presjek broja sudionika koji (ne) provode procjenu i/ili terapiju prikazan je u tablici 7. Podaci o mogućim razlozima koje sudionici navode za izostanak procjene i terapije poremećaja glasa u svom radu prikazani su na slici 4.

\section{Moguća rješenja za unapređenje obrazovanja i logopedskog rada u području poremećaja glasa}

U česticama 18-22 sudionici su imali priliku vrednovati moguće prijedloge za unapređenje obrazovanja i logopedskog rada u području poremećaja glasa. Predložene su im sljedeće mjere: više kolegija i praktičnog iskustva s osobama s poremećajima glasa; više članaka, edukacija i radionica, te umrežavanje logopeda sa specifičnim znanjima u području poremećaja glasa. Iako su svi prijedlozi pretežito označeni važnima, odgovori sudionika su najviše ujednačeni 
u vrednovanju potrebe za više praktičnog rada, edukacija $i$ radionica, te umrežavanjem logopeda.

U tablici 8 prikazani su odgovori logopeda u postocima.

\section{Provodite li terapiju poremećaja glasa?}

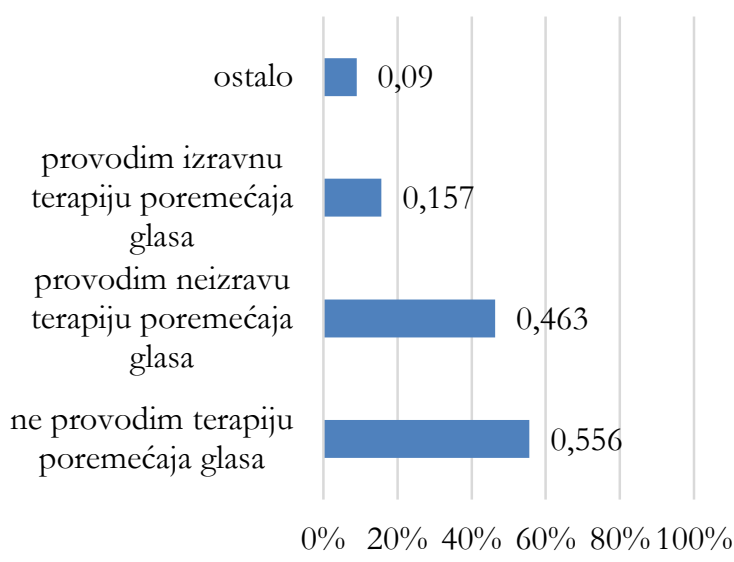

- udio ukupnog broja sudionika koji je odrabrao pojedini odgovor

Slika 3. Podaci o odgovorima sudionika o provedbi terapije poremećaja glasa

\section{Ako u radu ne pružate logopedske usluge djeci/odraslima s poremećajem glasa, označite moguće razloge:}

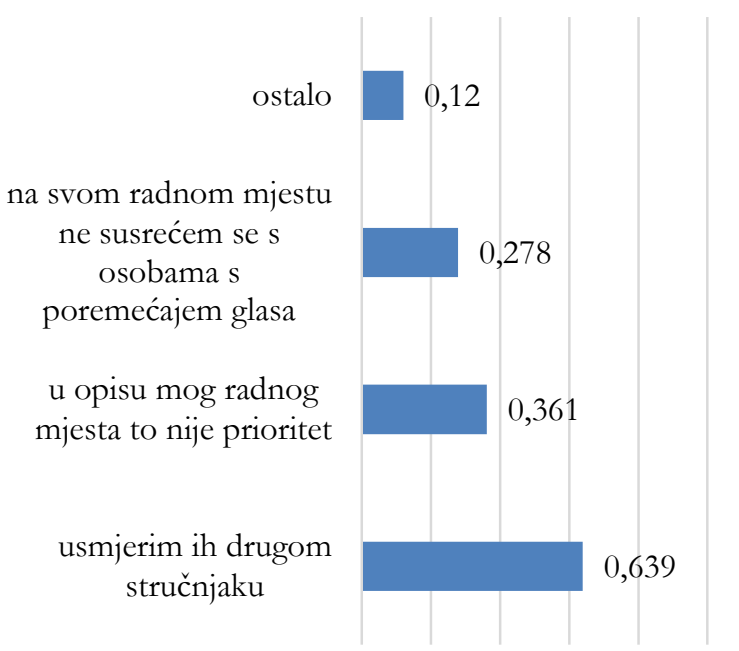

$0 \% \quad 20 \% 40 \% 60 \% 80 \% 100 \%$

udio ukupnog broja sudionika koji je odrabrao pojedini odgovor

Slika 4. Podaci o odgovorima sudionika o mogućim razlozima izostanka pružanja logopedskih usluga za osobe s poremećajem glasa i njihovom radu

Analizom prikupljenih podataka, prihvaćena je prva hipoteza (H1). Osobe s poremećajima glasa češće logopedske usluge dobivaju u sustavu zdravstva, nego u drugim sustavima. Ne iznenađuje da se upravo logopedi zaposleni u tom sustavu osjećaju najkompetentnijima za rad s navedenom populacijom. Ipak, taj osjećaj ne podliježe razlikama s obzirom na broj godina radnog staža, već je vjerojatno rezultat prioriteta radnog mjesta koji dovode do većeg iskustva rada s određenom populacijom, te dodatnih edukacija koje logopedi pohađaju nakon završetka formalnog obrazovanja.

Tablica 7. Presjek provođenja procjene i terapije prema broju sudionika

\begin{tabular}{|l|l|c|c|c|}
\hline \multirow{2}{*}{$\begin{array}{l}\text { Provođenje } \\
\text { procjene }\end{array}$} & \multicolumn{4}{|c|}{ Provođenje terapije } \\
\cline { 2 - 5 } & $\mathbf{N e}$ & $\mathbf{N e}$ & $\mathbf{D a}$ & Ukupno \\
\cline { 2 - 5 } & $\mathbf{D a}$ & 9 & 37 & 62 \\
\cline { 2 - 5 } & Ukupno & 56 & 52 & 108 \\
\hline
\end{tabular}

Tablica 8. Rezultati vrednovanja prijedloga o unapređenju obrazovanja i logopedskog rada u području poremećaja glasa (izraženi u postotku)

\begin{tabular}{|l|c|c|c|}
\hline Prijedlozi & $\begin{array}{c}\text { Nevažno } \\
\text { (\%) }\end{array}$ & $\begin{array}{c}\text { Niti } \\
\text { važno niti } \\
\text { nevažno } \\
\text { (\%) }\end{array}$ & $\begin{array}{c}\text { Važno } \\
\text { (\%) }\end{array}$ \\
\hline $\begin{array}{l}\text { Više kolegija na temu } \\
\text { poremećaja glasa }\end{array}$ & 9,3 & 21,3 & 69,4 \\
\hline $\begin{array}{l}\text { Više praktičnog } \\
\text { iskustva s osobama s } \\
\text { poremećajima glasa }\end{array}$ & 0,9 & 1,9 & 97,2 \\
\hline $\begin{array}{l}\text { Više članaka na temu } \\
\text { poremećaja glasa }\end{array}$ & 3,7 & 24,1 & 72,2 \\
\hline $\begin{array}{l}\text { Više edukacija i } \\
\text { radionica na temu } \\
\text { poremećaja glasa }\end{array}$ & 0,9 & 2,8 & 96,3 \\
\hline $\begin{array}{l}\text { Umrežavanje logopeda } \\
\text { sa specifičnim } \\
\text { znanjima u području } \\
\text { poremećaja glasa }\end{array}$ & 0,9 & 6,5 & 92,6 \\
\hline
\end{tabular}

Unatoč tome što je većina sudionika upoznana tijekom studija s različitim temama unutar poremećaja glasa, većina njih $(60,2 \%)$ nakon studija ne osjeća se pripremljeno za rad $s$ populacijom osoba $\mathrm{s}$ poremećajima glasa. Time je odbačena druga hipoteza (H2). Ipak, donekle pripremljeno osjeća se $37 \%$ sudionika. Rezultate koji ukazuju na osjećaj pripremljenosti kod sudionika, moguće je objasniti činjenicom da poremećaji glasa nisu postojali kao izolirani kolegij u izvornom nastavnom planu i programu studija, već su kasnije uvedeni.

Rezultati istraživanja pokazuju da je većina sudionika $(61,1 \%)$ imala neki oblik vježbi i/ili prakse u području poremećaja glasa. Unatoč tome, podjednak broj sudionika $(60,2 \%)$ nakon završetka studija nije se osjećao dovoljno pripremljeno za pružanje logopedskih usluga u navedenom području. Uz to, dodatno zabrinjava i činjenica da se osjećaj 
kompetencije ne povećava s radnim iskustvom, već uglavnom ostaje isti. Ipak, takav je podatak očekivan s obzirom na to da se, kao što i rezultati istraživanja pokazuju, većina logopeda zapošljava u sustavu odgoja i obrazovanja, gdje se logopedi gotovo i ne bave problematikom poremećaja glasa jer su u opisu njihova radnog mjesta drugi prioriteti. Prioriteti radnog mjesta usmjeravaju stručnjaka u razvoju vještina i kompetencija za rad $\mathrm{s}$ određenim poremećajima te ostavljaju manje prostora za razvoj u manje prioritetnim područjima. Dakle, rezultati potencijalno ovise upravo o sustavu u kojem je logoped zaposlen. Drugo moguće objašnjenje rezultata proizlazi iz manjka daljeg stjecanja znanja nakon studija. Čak $63 \%$ sudionika nikad nije sudjelovalo na edukacijama $\mathrm{i} / \mathrm{ili}$ radionicama nakon studija, a više od polovine sudionika nikad (21,3\%) ili gotovo nikad $(31,5 \%)$ ne čita stručnu literaturu o poremećajima glasa. Više od polovine logopeda u ovom istraživanju ne provodi procjenu $(59,3 \%)$ ni terapiju $(55,6$ $\%)$ poremećaja glasa. Možda je takav podatak očekivan $\mathrm{s}$ obzirom na opis, tj. uvjete i zahtjeve njihovih radnih mjesta. Naprimjer, čak ako im je neki postupak poznat i dostupan, kao akustička analiza glasa, on nije prioritet na njihovom radnome mjestu ili uvjeti radnog mjesta otežavaju provedbu. Sudeći prema rezultatima, postoji potreba za unapređenjem struke u ovom području s više kolegija, prakse, stručnih članaka, edukacija i umrežavanja logopeda, što i sudionici prepoznaju. Naravno, potreban je oprez u generalizaciji rezultata, s obzirom na to da namjerni i prigodni uzorak u ovom istraživanju nije reprezentativan prikaz struke, odnosno omjera stručnjaka zaposlenih u različitim sustavima unutar Republike Hrvatske.

\section{ZAKLJUČAK}

Poremećaji glasa problematika su koja u općoj populaciji još nije dovoljno osviještena, a svakako postoji potreba za njenim prepoznavanjem i tretiranjem. Provedeno istraživanje ukazuje na problem u praksi poremećaja glasa u Hrvatskoj. Diplomirani logopedi, nakon završetka studija, ne osjećaju se dovoljno pripremljeno za rad s osobama s poremećajima glasa. Čini se da godine radnog staža nisu čimbenik koji značajno pridonosi promjeni tog osjećaja, već on ovisi o sustavu u kojem je logoped zaposlen, a koji ga specijalizira $\mathrm{za}$ rad $\mathrm{s}$ određenim populacijama i/ili poremećajima. Prijedlog Zakona o logopedskoj djelatnosti (2011) navodi da - „područja rada (radna mjesta) logopeda ne utječu na postupke logopeda niti područje djelovanja logopedske djelatnosti koji su uvijek u funkciji prevencije, skrbi, potpore i rehabilitacije osoba $\mathrm{s}$ verbalnim i/ili neverbalnim komunikacijskim poremećajima. Logopedska djelatnost u zdravstvu, odgoju, obrazovanju, socijalnoj skrbi i privatnoj praksi obavlja se na temeljima istog stručnog rada logopeda koji se u svojem djelovanju razlikuje samo prema mjestu rada, ali ne i prema sadržaju rada."

Navedeni uvjeti zvuče idealno, međutim, u praksi danas to nije tako. U stvarnosti područje logopedskog rada određeno je radnim mjestom, što pokazuju i rezultati istraživanja. Primjerice, logoped u odgojno-obrazovnim ustanovama ima ulogu stručnog suradnika, što ostavlja manje vremena za neposredan rad s klijentima. Logopedija je u Hrvatskoj mlada znanost u stalnom napretku, koja se razvijala sporije nego u Europi i svijetu. U drugim zemljama čak su uobičajene (pod)specijalizacije za pojedina područja u logopediji, pa tako i za poremećaje glasa (https://www.speechpathologygraduateprograms.org/voicetherapy/). Mogućnost specijalizacije za određeno područje i nastavak edukacije, nakon studija, mogu ispuniti potrebe za znanjem i vještinama koje logoped u području poremećaja glasa mora imati (van Mersbergen, Ostream i Titze, 2001). Međutim, s obzirom na to da na diplomskom studiju Logopedija u Hrvatskoj još ne postoje moduli, možemo samo nagađati bi li takva vrsta specijalizacije za pojedino područje pridonijela osjećaju kompetencije i boljoj praksi u području poremećaja glasa. Znanje koje imamo brzo se mijenja, stoga postoji potreba za cjeloživotnim obrazovanjem i praćenjem literature radi pružanja najkvalitetnije moguće skrbi i logopedskih usluga.

\section{LITERATURA}

1) American Speech-Language-Hearing Association. (1993). Definitions of communication disorders and variations, $<$ www.asha.org/policy>. Pristupljeno 16. svibnja 2019.

2) American Speech-Language-Hearing Association (2004). Preferred practice patterns: Preferred practice patterns for the profession of speech-language pathology. Rockvile: American SpeechLanguage-hearing Associtatin.

3) American Speech-Language-Hearing Association (2019). Voice disorders. American Speech-Language-Hearing Association, <https://www.asha.org/PRPSpecificTopic.asp $\mathrm{x}$ ? folderid $=8589942600 \&$ section $=$ Treatment $>$. Pristupljeno 16. svibnja 2019.

4) Behlau, M., Oliveira, G. (2009). Vocal hygiene for the voice professional. Current Opinion in Otolaryngology and Head and Neck Surgery, 17(3), 149-154.

5) Chan, R. W. K. (1994). Does the voice improve with vocal hygiene education? A study of some instrumental voice measures in a group of kindergarten teachers. Journal of Voice, 8(3), 279-291.

6) Hrvatski zavod za zapošljavanje (2018). Preporuke za obrazornu upitnu politiku $i$ politiku stipendiranja. Zagreb: Hrvatski zavod za zapošljavanje, <https://www.azvo.hr/images/stories/novosti/HZZ\%20p reporuke_2018.pdf>

7) Kovačić, G., Buđanovac, A. (2000). Vokalna higijena: koliko o njoj znaju (budući) vokalni profesionalci? Hrvatska revija za rehabilitacijska istrą̌ivanja, 36 (1), 37-62.

8) (van) Mersbergen, M., Ostream, J., Titze, I. R. (2001). Preparation of the SpeechLanguage Pathologist Specializing in Voice: An Educational Survey. Journal of Voice, 15(2), 237250.

9) Pasa, G., Oates, J., i Dacakis, G. (2007). The relative effectiveness of vocal hygiene training and vocal function exercises in preventing voice disorders in primary school teachers. Logopedics. Phoniatrics Vocology, 32(3), 128-140.

10) Prijedlog zakona o logopedskoj djelatnosti (2011), $<$ https://www.sabor.hr/hr/prijedlog-zakona-ologopedskoj-djelatnosti-prvo-citanje-pz-br-756>. Pristupljeno 5. svibnja 2019.

11) Titze, I. R., Verdolini, K. (2010). Vocology: The science and practice of voice habilitation. Salt Lake City, Utah: National Center for Voice and Speech. 
12) Yiu, E. M.-L., Chan, R. M. (2003). Effect of Hydration and Vocal Rest on the Vocal Fatigue in Amateur Karaoke Singers. Journal of Voice, 17(2), 216-227. 